\title{
GlobalizATION AND THE Rise OF MEGA-CitiES IN THE DEVELOPING WORLD
}

\author{
FREDERICK VAN DER PLOEG \\ STEVEN POELHEKKE
}

CESIFO WORKING PAPER No. 2208

CATEGORY 7: TRAdE POLICY

FEBRUARY 2008

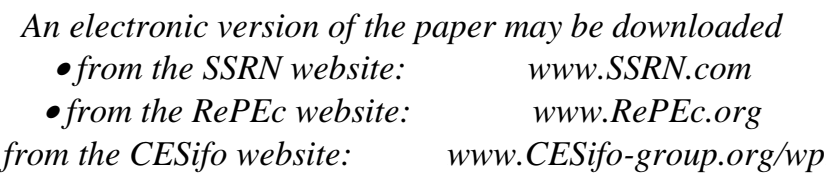




\title{
GLOBALIZATION AND THE Rise OF MEGA-Cities IN THE DEVELOPING WORLD
}

\begin{abstract}
Thomas Friedman has argued in The World is Flat that those who deny rapid globalization will not survive in the global economy. First, we critically discuss Friedman's views and highlight the new globalization driven by outsourcing and vertical specialization. Second, we argue that Friedman pays insufficient attention to the spectacular growth of mega-cities in the developing world. The world is not flat, and the developing world certainly is not. Still, megacities tend to become too big. Their growth also goes hand in hand with formation of slums and congestion. We thus argue that there is a role for public policies.
\end{abstract}

JEL Code: F01, H40, O10, R10.

Keywords: globalization, unbundling, off-shoring, mega-cities, congestion, public policies.

\author{
Frederick van der Ploeg \\ Oxcarre, Department of Economics \\ Oxford University \\ Manor Road Building \\ Manor Road \\ Oxford OX1 3UQ \\ United Kingdom \\ rick.vanderploeg@economics.ox.ac.uk
}

\author{
Steven Poelhekke \\ European University Institute \\ Department of Economics \\ Villa San Paolo \\ Via della Piazzuola, 43 \\ 50133 Florence \\ Italy \\ steven.poelhekke@eui.eu
}

Revised January 2007

I benefited from the discussions resulting from chairing a lively public debate with Thomas Friedman on The World is Flat on 4 June, 2007 in The Passenger Terminal Amsterdam organized by SEO and Delta Lloyd. 
Globalization combined with the advent of the Internet and the accompanying revolutions in communications technology have transformed the world. Numerous newspaper articles document the effects of outsourcing, in-sourcing, off-sourcing and many other phenomena that have increased global competition in recent decades. It is fair to say that many citizens feel threatened by these developments. But many of the routine, low-skilled jobs have already moved to countries with abundant cheap labour. Many of the higher skilled jobs ranging from teachers, accountants, computer programmers and technical drawers to radiologists are now also threatened by outsourcing. Thomas Friedman in his influential book The World is Flat argues forcefully that the world has changed forever and that those who fail to adapt and specialize and develop specific skills will find their Waterloo in the harsh global competition with countries like India and China. Compete or perish seems to be lesson from reading this book. Still, many economists feel uncomfortable with much of the arguments offered by Friedman.

Our aim is to first present a brief review and critique of the thesis on globalization, digitalization and the ensuing revolutions for workers, consumers and firms put forward by Thomas Friedman in his book The World is Flat. We then explain that most of Friedman's arguments derive from the so-called second unbundling of tasks within factories and offices. Globalization and the ensuing global competition increasingly takes place task by task rather than sector by sector or firm by firm. In view of the rapid urbanization of especially developing countries and the arrival of megacities, we argue that the metaphor The World is Flat is misleading as people and firms benefit so much from being humped together. In fact, mega-cities tend to become too large from a social perspective and attract too much labour from rural areas, especially in developing countries. We also argue that the process of urbanization and development can and should be aided with public policies, such as public infrastructures and public education, if slums, congestion and other negative side effects are to be avoided. We want to make clear at the outset that our paper is a critical and eclectic appraisal of Friedman's influential work, which is directed at political scientists, geographers and public policy scholars as much as at professional economists. It is an essay which makes use of insights from the available literature on international trade, development economics and urban economics to gain new insights on the issues of globalization, urbanization and the rise of mega-cities.

The organization of our paper is as follows. Part I constitutes the first half of the paper and deals with the globalization aspects of Friedman's arguments. Section I.1 tries to get to grip with the main theses of Friedman's The World is Flat and argues that, despite the undeniable trends towards globalization and digitalization, many of the knowledge-intensive jobs in the Western world are not contested by outsourcing and low-wage labour from the developing world. Buyers and sellers have indeed become more footloose, but cities surprisingly offer many advantages of agglomeration. Neither have wages in the Western and developing world converged. Most of international trade is with neighbouring countries, so that the "death of distance" is not a helpful metaphor. Section I.2 highlights the second 
unbundling, which amounts to fragmentation of production and outsourcing of individual tasks within the production process. This contrasts with the first unbundling of consumption and production, which was mainly driven by lower transport and communication costs. Now most of the unbundling concerns the off-shoring of mundane, codifiable tasks across many different sectors, so that the losers of globalization are much harder to identify. Compared with the normal creation and destruction of jobs, outsourcing is still pretty insignificant. Yet, there is evidence that it depresses wages of the low skilled and boosts wages of the higher skilled workers. Growing inequality is thus a phenomenon of the recent waves of globalization.

Before policy conclusions can be discussed, the second part of this paper draws out the relationships between globalization and urbanization in the global economy. Section II.1 discusses the rapid urbanization in the world economy. Half the people on this planet now live in cities and the degree of urbanization increases especially in the developing world. Cities attract increasing numbers of people from the country side. This has led to a rapid increase in mega-cities with more than ten million inhabitants. Section II.2 takes a developing economies perspective and discusses the merits of urbanization and mega-cities. Section II.3 gives the bare bones of a theory of optimal city size, which balances agglomeration advantages and congestion costs. Section II.4 then makes the case that many of the African mega-cities have not enjoyed the fruits of globalization. In contrast to the Asian policies directed at balanced urban growth and avoidance of too few and too large cities, Africa suffers from the problem of primacy and stagnating mega-cities. This may be due to trade restrictions that favour manufacturing and service activities, political favouritism, excessive number of slums and high rents in the informal housing market in African cities.

The third part of the paper wraps up. Section III.1 offers policy recommendations for, on the one hand, balanced urbanization to ensure development of a variety of cities and avoid urban primacy, and, on the other hand, social policies to offset the harmful effects of globalization. Section III.2 wraps up with some concluding remarks.

\section{PART I: GLOBALIZATION}

\section{I.1. Globalization, Digitalization and Is the World Really Flat?}

Globalization has been driven by the falling costs of transport and communication ever since the introduction of steamships, railroads and the telegraph as described so vividly in Standage (1998) on the 'Victorian Internet'. To put it another way, the engine of globalization has been steady reductions in the costs of moving goods, capital, people and ideas. Recent technology improvements have had huge measurable effects. The real costs of moving goods between US cities dropped by over 90 percent during the $20^{\text {th }}$ century, according to Glaeser and Kohlhase (2004), when road transportation 
started to replace water and railway transportation. During the second half of the same century the cost of air transportation has dropped as well (Hummel, 2008). During the two world wars and the Great Depression the ugly head of protectionism reared its head. Since World War II many trade barriers and the costs of transport have fallen with the advent of modern airlines and mass tankers. Most dramatically, with the extremely rapid development of email and the Internet, the costs of communication have fallen. This has prompted many to argue that the world has become a "global village" and to argue with slogans like "the death of distance". Friedman (2007) has used it to fuel his metaphor of "The World is Flat". His views have become very influential in policy making circles and with the general public, but have been criticized at length by academic economists. Birdsall (2005) argues that the world is far from flat, since many unequal opportunities persist at the level of households within countries and at the level of nations and the forces of globalization seem to exacerbate these inequalities. The most detailed and coherent economic critique of Friedman's book is probably due to Leamer (2007). Leamer has some problems deciphering the blurb of Friedman's book:

“..the convergence of technology and events that allowed India, China, and so many other countries to become part of the global supply chain for services and manufacturing, creating an explosion of wealth in the middle classes of the world's two biggest nations and giving them a huge new stake in the success of globalization? And with this "flattening" of the globe, which requires us to run faster in order to stay in the same place, has the world gotten too small and too fast for human beings and their political systems to adjust in a stable manner?"

Just as Columbus' discovered the Indian natives in America, Friedman found that the Indian people in Bangalore were American in name and speech and business practices. This is where Friedman had his flash of insight that The World is Flat. Friedman discusses ten forces that "flatten" the world: (1) the fall of the Berlin Wall in 1989; (2) the birth of the Internet in 1995 with the going public of Netscape; (3) work flow software to coordinate tasks; (4) open-sourcing (e.g., Linux or Wikipedia); (5) outsourcing (e.g., mundane and increasingly more sophisticated coding of software from the US to Bangalore, routine and labour-intensive drawings of architect plans, call centres); (6) off-shoring manufacturing jobs to developing countries with low wages; (7) supply chains (e.g., Wal-Mart or DAF buses); (8) in-sourcing (e.g., UPS picking up and fixing your laptop); (9) in-forming (e.g., Google); and (10) the so-called "steroids" (mobile internet, videoconferencing, etc.). Undoubtedly, these ten forces have and are transforming the world, but have they "flattened" (whatever that means) the world? Leamer (2007) argues that the huge increase in unskilled workers due to the opening up of China, India, Russia and South America is just as important a force in the march towards progress. The advent of Internet and the resulting disappearance of helpers and middlemen, and the spurt in communication innovations have made it possible for people to focus on inspiration rather than perspiration, not a mean feat. And with the Internet it is possible to order goods and services from all parts in the world. This has expanded the set of consumption opportunities, reduced monopoly power 
and lowered costs. In some cases, the new technology has fundamentally altered how business is done (think of the music industry). Most important, the new ICT technologies have greatly improved the opportunities for exchange and thus made possible a further division of labour and huge improvements in efficiency along the lines discussed by Adam Smith in his An Inquire Into the Nature and Causes of the Wealth of Nations more than two and a quarter centuries ago.

Although these latter trends could be seen to flatten the world, Leamer (2007) and many others have problems understanding what is meant by the world is "flat" from the perspective of traditional theories of economic geography. The old Von Thünen and Hotelling models suggest that geography constrains competition and creates long-term relationships between buyers and sellers. Farm land is sold at a premium near the city centre to reflect lower transportation costs and thus crops with a high value added are produced closer to the centre of the market town. Christaller's classical (1933) theory, extended and modified by Lösch (1938), of minimizing the average distance between consumer and supply point cuts a never-ending featureless plane into equal-sized hexagons with supply points located at the centre of each hexagon, but does not seem compatible with The World is Flat metaphor either. Leamer (2007) concludes that geography creates cost-advantaged relationships between sellers and buyers who are located "close" to one another. Economic geography is not concerned with "What if the world is flat rather than bumpy?" but with "How do lower transportation costs affect competition and regional inequalities?”. It makes more sense to argue that falling costs of transport and communication and global networks of knowledge have made the world "smaller", so that buyers and sellers become more footloose and competition is more intense. Still, economic geography matters (think of Hollywood and Bollywood for films, Silicon Valley for electronic innovations, Manhattan and the City of London for finance, clothing in Prato, Italy, or the flower exchange market in the Netherlands, etc.). Buyers and sellers like to deal with others they know and trust. Such long-run relationships are key to trade and are not easy to break by far-away low-skilled workers.

Leamer (2007) argues convincingly that many of Friedman's arguments are flawed. Many of the most knowledge-intensive jobs are not contested by outsourcing, since experts want to live and work in the same area in order to learn and profit from each other. The fears that much of their work is commoditized and sold in global markets and that wages in the North will be set by the abundance of workers in the South are simply unjustified. Friedman's claim that, not only routine tasks, but also secure, negotiable higher skilled jobs will be transformed into insecure contestable jobs does not ring a bell either. Not all products will be standardized and priced accordingly, but prices of customized, specialized goods will be negotiated and the markets for those goods are likely to be contested by global competition. In fact, much of the production of apparel, leather products, fabricated metal products and electrical equipment, appliances and components has already moved to developing countries and thus there are not many jobs left to be contested in those sectors. Other sectors such as the professional finance and insurance sectors or the motion pictures are specialized and rely on agglomeration externalities, so jobs in those sectors are less likely to be contested by global 
competition. Of course, the mobility of ideas and transfer of knowledge has increased enormously with the globalization and digitalization of the economy. This offers parts of India and China genuine opportunities to set up their own Silicon Valley and Hollywood. Researchers want to hump together in order to be creative and productive and ideas can be quite footloose, so it makes more sense to subsidize higher education than to subsidize $R \& D$. There may also be reasons to make cities more attractive to the creative class by having a rich cultural climate as argued by Florida (2005). The key insight is that mainly jobs or tasks that are mundane and codifiable are contested by global competition.

The main problem is that much of Friedman's thesis is based on informal discussions with key players in the global economy without a proper and detailed analysis of the statistical facts of globalization. Leamer (2007) points out that the global income distribution has not become flatter, neither between countries nor within the US (and most other Western countries). The Great Equalization of factor incomes, where wages and per capita incomes in the poorest part of the world rise dramatically towards those in the richest part of the world has not occurred (yet). India and China have made immense progress during the last twenty years, but the US, Japan and some other rich countries have grown very fast as well. Many of the other middle-income countries that initially managed to attract low-wage manufacturing jobs from the high-wage countries have lost ground to China and India. People in different parts of the globe are not identical and are not performing the same tasks. For example, the few agricultural workers that are left in the rich countries typically have access to very expensive and efficient machinery for planting, cultivating and harvesting, whereas a lot of this work in the poorest country is done by hand.

Contrary to what many advocates of the "death of distance" claim, empirical gravity equations suggest that international trade is much stronger between countries that are geographically close (and large). Indeed, most of trade of EU is intra-European. In that sense, the world is not flat and the dramatic falls in transportation and communication costs has not made the world flatter either. The surge in Asian products sold in the US and Europe is due to the rapid economic growth in China and India, not due to the "death of distance”. Much of the buzz of economic activity is due to face-to-face contact as shown by Storper and Venables (2004). This is an efficient means of communication, it promotes socialization and learning, and provides better incentives and psychological motivation, especially when information is imperfect, changing rapidly and not easily codified. Astonishingly, Blum and Goldfarb (2006) show that US Internet users favour foreign websites close to the US and thus geographic proximity determines action on the Internet as well. As forcefully argued by Bhagwati (2004) and many other economists, the wage of an individual worker depends on education, experience, talent but also on where he or she lives and works. Leamer (2007) argues that the decline in manufacturing jobs is only affected a small amount by international trade. Outsourcing of intellectual work is actually very small (and much smaller than is hyped in the press) and the US is extremely well placed to compete in the Internet-segment of the economy. Leamer (2007) makes clear 
that not more than a few percentage points of jobs are off-shored each year, which is a mere fraction of the number of jobs being destroyed and created each year. This is not surprising given that bilateral trade in goods decreases by about 9 percent for every 10 percent increase in distance; an effect that has not diminished during the last half a century according to Disdier and Head (2008). This might be due to more than transportation costs, for example due to culture. Moreover, since off-shoring requires tasks to be delivered down the Internet, they have to becodifiable and require little face-to-face interaction. Many jobs (of, say, barbers, taxi drivers, nurses or schoolteachers) are simply not affected. In sum, although The World is Flat is a persuasive metaphor backed up by plenty of interesting anecdotes, its main thesis does not seem to stand up to the facts. However, recent work by Geishecker and Görg (2007), using a large household panel and detailed industry level data, on industries' outsourcing activities does find a significant effect of outsourcing on wages. A one percent increase in outsourcing reduces the wage of the lowest skilled workers by 1.5 percent whereas it increases the wage of the highest skilled workers by 2.6 percent. Globalization has thus increased income inequality between low skilled and high skilled workers.

\section{I.2. The Second Unbundling: Globalization, Outsourcing and Fragmentation}

To gain better insights into the phenomenon of globalization and the thesis put forward in The World is Flat, it helps to follow Baldwin and Martin (1999) and distinguish two types of unbundling in the process of globalization. We base much of the discussion in this section on Baldwin (2006). The first type of unbundling was driven by falling transport and communication costs and took place during the years 1850-1914. Effectively, it was no longer necessary to make goods close to the point where consumption takes place. It was driven by industrialization of the US and Western Europe (the North and de-industrialization of India and China (the South), an explosion of international trade in goods and factors of production, and a rapid and historically unprecedented urbanization in the North. This first unbundling was accompanied by stagnating incomes per capita in the South and rapid growth in the North, thus leading to a massive divergence between incomes in the North and South. The second unbundling took off in the 1960s and shows marked differences with the first unbundling. The South (East Asia) has been and is industrializing rapidly while the North continues to de-industrialize and shift from manufacturing to services.

After the return to protectionism set off by two world wars and the Great Depression, the second unbundling saw a rapid liberalization of trade and capital flows. Together with the rapid falls in communication and coordination costs, this has led to a big wave in vertical specialization and offshoring of service-sector jobs. Whereas the first unbundling implied a spatial separation of factories and consumers, the second unbundling led to a spatial unpacking of factories and offices themselves and a slicing up of the value-added chain as argued by Baldwin (2006). The fragmentation characteristic of the second unbundling wave of globalization has resulted in spectacular growth in the 
industrializing giants China and India (four or five times faster than during the Industrial Revolution) and a modest slowdown of growth in the North. Although India and China seem to be catching up, many of the middle-income countries are loosing ground to India and China and their growth rates are trailing behind those of the US and Japan as well as of China and India. The growth during the second unbundling was accompanied by further rapid urbanization, especially in China and India. However, the experience of Africa indicates that urbanization does not always go hand in hand with higher growth in income per capita (see Section II.2). Interestingly, inequalities in income and unemployment outcomes increased substantially in the North.

Available theories of international trade go a long way towards understanding the first unbundling. International trade in goods and migration has led to more efficient outcomes and static and dynamic gains of trade. Globalization has also led to expanding markets and exploitation of scale economies in the production of manufactured goods. There are also strong forces that boost spatial clustering. People and firms settle in big cities in search of better jobs, the need for face-to-face interaction, and the stimulation of the buzz of learning from each other. They do this despite high costs of commuting or of living in the cities and despite congestion and air pollution. But the agglomeration forces operating due to globalization and the desire to be close to consumers and suppliers (leading to demand side or forward and supply side or backward linkages) operate on a much larger geographic scale and span many countries. They result in dense networks of suppliers, manufacturers and infrastructure and set in motion a process of cumulative causation. Since under autarky production is necessarily bundled with consumption and under completely free trade (i.e., no tariffs, no transport costs, etc.) location of production is irrelevant, the forces of agglomeration are strongest at intermediate degrees of trade and transport costs. This hump-shaped feature of agglomeration explains why cities grew so much in the North during 1850-1914 and in the South from the 1960s onwards. Agglomeration advantages are further fuelled by Paul Krugman's home market effect (1980). Effectively, returns to scale and imperfect competitiongive large national markets a disproportionate share of world industry, because market-access (expenditure) advantages outweigh market-crowding disadvantages. Firms want to locate near their consumers. Still, firms do not locate all in the same place as local competition (due to trade costs providing protection against competition from firms elsewhere) is strongest in the biggest market. The home market effect is magnified through freer trade when production becomes more footloose, while expenditure from locally earned wages is still mainly spent locally. A larger market will then attract even more industry (Krugman, 1991).

The losers of the first wave of globalization could be helped by specific compensation to the most adversely affected sectors, workers and firms, and by retraining wherever possible the displaced work force. Sectors, not tasks, were hurt by the falling cost of trading goods rather than of trading ideas during the first unbundling. The sectors in the US and Europe with the lowest comparative advantage on international markets were unable to compete with cheap labour abroad at prevailing 
wage levels even if wages fell to the level of welfare/unemployment benefits. These sectors thus perished. With falling trade costs, the sectors with the highest comparative advantage benefit while sectors with the lowest comparative advantage (including the sectors constrained by the severest form of labour market regulation) would be hurt most. This is more or less what happened to textiles, electrical products and other manufacturing sectors relying on low-skilled labour in Europe during the first unbundling. The winners of the first wave of globalization in the rich countries were thus the high-skilled workers and the losers the low-skilled and unskilled workers. The richer high-skilled workers are also the ones that applaud immigration of cheap low-skilled workers. At the same time, unskilled workers are hurt which explains the upsurge of populist anti-immigration sentiments among the traditional working classes in much of Europe. There has been a steady fall in the number of routine tasks to be performed and an increase in the upgrading of skills, which is great as it offers ample opportunities for technical progress. The policy response (e.g., witness the Lisbon Agenda) has been to put (mostly in rhetoric) education on top of the political agenda and to attempt to shift towards an "information society". But it is not clear that it is so easy to predict winners and losers during the second wave as it was during the first wave of globalization.

To get a better grasp of the second unbundling, we need to disaggregate beyond the level of an individual firm and depart from the idea that all production stages are spatially clustered in a single plant or office. The first unbundling benefited skill-intensive sectors, but damaged the position of unskilled, labour-intensive sectors in the North. The second unbundling introduced global competition into factories and offices on a task-by-task rather than a firm-by-firm or sector-by-sector basis and has led to international trade in tasks rather than trade in goods and services as argued by Blinder (2006) and Grossman and Rossi-Hansberg (2006). It is this revolution which is transforming much of the world today and has been highlighted dramatically by Friedman's The World is Flat. A telling example of the second unbundling is the explosion in the 1980s of Japanese companies that off-shored labour-intensive production stages to cheaper, nearby East Asian countries. Apparently, the productivity advantage of Japan over China and its neighbours more than justified the Japan-China wage gap. Consequently, there was no fall in industrial employment in Japan. The off-shoring made Japan, in fact, more competitive in the US and European markets. Baldwin (2006) talks of the "hollowing out" of the Japanese economy and of East Asia splitting up in head-quarter economies (Japan later followed by the Asian Tigers) and factory economies. Another telling example of the second unbundling is the off-shoring of previously non-traded tasks such as call centres in the US and UK to India. The second unbundling has been extended to intermediate goods and services.

The second unbundling involved the off-shoring of mundane, codifiable tasks (e.g., data entry or bookkeeping) across a diverse variety of labour- and capital-intensive sectors, so that it is not possible to identify winners and losers from globalization according to the sectors they work in or even the skill group they belong to. It thus makes sense to rank tasks rather than sectors according to comparative advantage and competitiveness. But some tasks (e.g., reception services, protection 
services or driving a truck) are hardly affected by reduced costs of communication, coordination and transferring ideas, while other tasks (e.g., call centre services, software design) are very much affected. Now the winning and losing tasks of globalization are much tougher to predict due to the complex interactions with other tasks in each factory or office. Wages of many workers currently performing non-trading tasks in the developed countries are not justified by their productivity, so the second unbundling may threaten their income or their job. Coordination costs are convex, since it is better to have most people working together, whether it is in a call centre in Amsterdam or in Paramaribo. After a certain point, the balance is tipped and all call centre tasks are off-shored. The situation is thus complicated by the suddenness and unpredictability of off-shoring. The New Economic Geography highlights the agglomeration economies of backward and forward linkages in moving goods, people and ideas. The humpy nature of agglomeration economies also points to a critical mass in the process of development. Marginal changes can lead to sudden and large shifts in tasks. There has not been much off-shoring of financial services, but it may suddenly happen at a large scale.

Of course, the second unbundling corresponds in a real sense to technical progress because trade in intermediate goods and services implies that more output can be produced from the same inputs. Just like Luddites opposed the introduction of new technologies (e.g., newspapers were for some time set electronically as well as by hand to pacify the trade unions), many oppose fragmentation and the associated off-shoring. But off-shoring should be seen as a boon rather than a curse. In this sense, it is not very different from technical progress. Grossman and Rossi-Hansberg (2006) suggest that the impact of off-shoring on wages, of say bookkeepers in the developed world, operates via the terms of trade, jobs and productivity: off-shoring to low-wage bookkeepers lowers the price of bookkeeping, which harms the real wage of bookkeepers in the developed world; also demand for bookkeepers in the developed world falls which lowers wages (or causes unemployment among bookkeepers) in the developed world; and workers in the developed world will focus on higher productivity activities which exerts upward pressure on wages. If the productivity effect dominates the terms of trade and jobs effects, then off-shoring of routine, manual tasks is a boon for society as it allows workers to concentrate on non-routine, more analytic tasks demanding face-to-face interactions, continual fine tuning and trust. This shift clearly boosts productivity, wages and morale. Indeed, Grossman and Rossi-Hansberg (2006) show that the share of non-routine tasks has increased while that of routine tasks has fallen in the US since 1970. 


\section{PART II: URBANIZATION}

\section{II.1. Rapid Urbanization and the Growth of Mega-Cities in the Developing World}

Outsourcing, unbundling and fragmentation of firms has, however, not lead to general dispersion of activities across the globe. Many more countries now have stronger links with world trade even if they are far away from the major consumer markets of the EU and US. However, within these countries most activity is concentrated in a few metropolitan areas. We argue that rapid urbanization, especially in the developing world, has been one important feature that has developed rapidly in the wake of the waves of globalization and is overlooked by the supposed flatness of the world. Urbanization has been increasing around the world and has reached the 50 percent mark last year. ${ }^{1}$ Half the world population thus lives together in cities rather than spread across the countryside. After describing the facts of urbanization in various parts of the world, the next sections look at the costs and opportunities of urbanization in the light of globalization. In particular, we explain why some mega-cities grow at very rapid rates and manage to reap the benefits of the new wave of globalization while other mega-cities grow very rapidly as well but suffer from high levels of underemployment and unemployment. Indeed, some mega-cities may be too large and suffer from slums, pollution and other congestion problems. Our main point is that, if urbanization is really a crucial feature of globalization, then The World is Flat metaphor seems difficult to swallow and at least misses some crucial aspects of globalization.

Table 1 and Figure 1 show the progressive increase in urbanization across different geographical regions. Urbanization levels are high everywhere and are increasing very rapidly in the developing world. Fast growing regions such as East Asia and the Pacific are now as urbanized as Western Europe was in 1970. This roughly coincides with the average level of GDP per capita in East Asia and the Pacific reaching 1970 levels of Western Europe. Figure 1 indicates that urbanization and growth in GDP per capita go hand-in-hand as countries develop and transform themselves from a rural-agricultural structure to an urban-industrial economy. Industrial job creation in cities and the consequent prospect of a well-paid job is a powerful force for people to move from the countryside to urban centres. China placed itself at the receiving end of footloose manufacturing and has been able to put its massive population to use in cities, where industry has clustered to make use of agglomeration economies. The growing global demand for cheap labour has induced migration from rural areas to the coastal provinces, although partly government planned in the case of China (Au and Henderson, 2006a). Urbanization is thus generally viewed as a transitory process that accompanies income and job growth (Henderson, 2004; Lucas, 2004). It is akin to the frontier expansion of the rapid development of the United States in the period before the industrial revolution (Barbier, 2006). Higher income countries are almost fully urbanized while less developed countries have much lower levels of

\footnotetext{
${ }^{1}$ De facto population living in areas classified as urban according to the criteria used by each area or country (United Nations, 2006).
} 
urbanization. Figure 1, however, shows that urbanization can also occur without growth in income per capita, notably in Sub-Saharan Africa and also for some time in Latin America. Fay and Opal (2000) and Davis and Henderson (2003) explore the influence of government policies on shaping the concentration of people and industry in cities. Policies as tariffs, subsidies and price controls affect the sectoral composition through terms of trade effects between agriculture and modern industry and thereby tend to favour the urban manufacturing sectors.

A high share of the national urban population living in the largest city is another phenomenon of mainly developing countries. Table 2 shows the degree of concentration of the urban population within countries. In 1995 a staggering 40 percent of the total urban population (25 percent of the total population) in Latin America lived in one single city. The same is true for Sub-Saharan Africa, where the level of concentration has been on the rise since at least 1960. Faster growing and definitely developed countries appear to have much lower levels of urban concentration and levels have been declining. Based on Williamson (1965), Davis and Henderson (2003) address this issue and find an inverted U-shaped relation between development and the concentration of urban inhabitants in a single city. The mechanisms through which this works are initially unequal growth within countries and subsequently other regions catching up. Unequal growth within countries is thus a clear sign that economic opportunities are better in a few concentrated places.

Table 3 lists the largest cities in the world, namely those with over ten million inhabitants, and shows the fast pace of growth of these mega-cities in developing countries. In 1975 only Tokyo, New York-Newark and Mexico City had more than ten million inhabitants, but a quarter century later many cities in the developing world have joined the club of mega-cities. Apart from Los Angeles and OsakaKobe, all new entrants in the rankings are all from less developed countries. São Paolo, Mumbai, Shanghai, Delhi, Kolkata, Rio de Janeiro, Buenos Aires, Dhaka, Moscow, Karachi, Cairo, Manila, Lagos and Beijing have all surpassed the ten million inhabitants mark and more are expected to follow in the near future.

Globalization may well have increased the returns from living with so many people clustered in one place. On the downside it poses enormous challenges in most relatively poor countries, since a big chunk of city growth is due to rapid growth in informal employment and informal housing (slums). Most of these new mega-cities are situated in fast growing Asia, but not exclusively. Table 4 also shows the big contrast between the largest cities and cities of other sizes. The yearly growth rates by city-size classification fluctuates as cities move up the scale, but the average across years clearly shows that population growth rates (both natural and in-migration) are much higher in the largest cities and also much higher in less developed countries. The fact that these trends coincide with globalization begs for a closer look. The growth rate of the population in smaller (or new) cities is also sizeable at 19 percent every 5 years. The next section examines the potential benefits of these agglomerations. 


\section{II.2. Benefits of Urbanization and Mega-Cities: a Developing Economies Perspective}

The benefits of cities consist of the agglomeration forces that attract firms and workers, which allow them to be more productive than they would have been on their own, or allows them to serve a larger local market. One reason on the production side for industry to concentrate, is to share inputs, which are either immobile, costly to replicate (e.g., infrastructure such as a harbour) or costly to transport. For example, traditionally production took place close to mines and currently close to research centres, in a cities like Boston, Cambridge, Mass., Cambridge, U.K.. If certain locations are endowed with a crucial input for production that cannot be replicated easily, then industries will seek out these locations. In that sense, globalization has made the market global and increased the number of production locations to choose from, depending on the type of task, because production need not take place close to market anymore.

The growth of large agglomerations suggests that there is still a demand for local increasing returns to scale activities even though the often mentioned "death of distance” suggests that production might as well take place in the middle of nowhere. Lower transportation and communication costs allow a firm to choose a far-away location for its manufacturing. Yet, it will still choose a location with the right comparative advantage for its particular product and with the right infrastructure to be able to ship products to consumers. Typically, comparative advantage is strongest in cities, because in cities it is worthwhile to invest in infrastructure as the high costs can be spread over many people and firms. Comparative advantage may take the shape of a large pool of cheap labour, but can also take the shape of risk sharing as substitutes for suppliers may be found more easily in cities. Most suppliers are found in cities rather than in rural villages. These particular benefits are larger in mega-cities than in small cities. If urbanization takes the form of an expansion in the number of cities, then this may also increase the number of locations to choose from. Consequently, this allows better matching between firms and production locations. The unbundling of production processes has triggered an intensified search for the right location to produce. Each step on the way to a final product can now be produced in separate locations. Since this holds for many firms and products, similar tasks will end up clustered in the same area as close as possible to the ideal location. From there, lower transportation costs allow firms to reach the world market.

A good location for a particular firm may become even better if other firms join the same agglomeration. Local increasing returns have many micro foundations as described in more detail in Duranton and Puga (2004) and summarized in Overman and Venables (2005) for the context of a developing country. A bigger concentration of firms allows access to greater product variety and greater specialization of each firm. Learning is easier if there are more firms to learn from. These benefits are referred to as thick goods markets. Entrepreneurs may find it easier to obtain finance and venture capital in a larger city. Furthermore, it is easier for firms to learn about and search for new technologies which they will do more intensively due to increased local competition. 
Thickness also exists in the labour market. Firms can hire from a larger pool of workers allowing them to find a better match and find more specialized labour. This is in itself an incentive for workers to acquire those skills. A larger city may also provide such specialized labour in relative abundance, such as software engineers in Bangalore, making them cheap and competitive in the light of the second unbundling. Workers may also benefit from a larger market through labour poaching if firms bid up wages for strategic workers. Co-location may break down if competition becomes too intense. However, labour pooling benefits usually dominate (Combes and Duranton, 2006).

A larger city allows better market access, which is composed of demand (or backward) linkages and cost (or forward) linkages. The first leads to clustering, since firms that supply other firms are drawn to the cluster. For example, a concentration of call centres can induce a supplier of educated workers (say, a school) to join the agglomeration. The latter implies that firms will also seek out a location close to their essential suppliers. These reinforcing agglomeration forces are stronger if transportation costs are high. Transportation costs not only include shipping costs, but in a broader sense include trust and the risk of losing critical technology to competitors that come with outsourcing. This distinction may explain the coexistence of long-haul transportation of goods and short-distance relation-based production in a few agglomerations. Public good provision is also realized more efficiently in a larger city, because the often large fixed costs of public infrastructure make more sense in a larger city. This not only improves quality of living, but may also have productivity enhancing effects. Better health of workers is often used as an argument for high efficiency wages in developing countries (Stiglitz, 1976). Wages could be lower and employment higher if such health care is publicly provided.

Apart from the above static effects leading to increasing returns to scale, there are also dynamic effects in cities. Rodrik (2004) argues that development depends on a cost discovery process, that is entrepreneurs have to discover that a certain product may be produced more cheaply in the local city. The discovery arguably takes place with higher probability in a large city, also in developing countries. Hausman and Rodrik (2002) argue that such knowledge eventually becomes public and thus leads to local specialization in production as is often found in developing countries. This means that a nursery city argument as put forward by Duranton and Puga (2001) may also be relevant for developing countries (Overman and Venables, 2005). Diverse cities facilitate learning about the viability of new products, which are then produced in cities that have a comparative advantage to do so. More and larger cities (urbanization) create more locations with the associated opportunities for learning, production and trade. Taking this argument further, we dare say that urbanized countries are better positioned to reap the benefits of globalization than not-yet urbanized countries, both in the developed world (knowledge spill-overs) and in the developing world (manufacturing related spillovers). It thus pays to agglomerate, even in a flat globalizing world. This deserves more attention than is given in Friedman's The World is Flat. 
The benefit of cities for the location of firms naturally leads to the suggestion that cities and urbanizing countries form the preferred location for foreign direct investment (FDI). The empirical literature on FDI has not paid much attention yet to the role of urbanization explicitly, but there is evidence that factors typically found in cities play a role in attracting FDI. Noorbakhsh, Paloni and Youssef (2001) show that countries with high levels of human capital, buoyant labour growth and substantial international trade attract significantly more FDI (using a sample of 36 countries for the period 1980-94). All three of these factors can be found in relative abundance in cities. Hsiao and Shen (2003) find positive but weakly significant effects of urban-related variables (such as the urbanization rate, number of telephone lines and number of city lights) on FDI flows towards developing countries and Chinese provinces. Their data set is unfortunately relatively small (23 countries for the period 1976-97 and 1996-98 for China). Noorbaksh, Paloni and Youssef (2001) recognize, however, that FDI can be directed towards resource extraction, although this was more relevant in the 1950s. ${ }^{2}$ This is not an urban activity, but FDI flows have subsequently been directed towards locations with low labour costs and increasingly towards locations with educated labour. These factors appear more important than (local) market size in developing countries, which is consistent with FDI and export led growth. $\mathrm{Au}$ and Henderson (2006b) also stress the importance of local labour growth. The lack of migration limited sectoral agglomeration in China and weakened GDP growth. Agglomeration economies in turn feature as a core determinant of local firm activity (Baldwin et al, 2003) and may thus matter for FDI.

Growth in Asia has taken off through low-skill and labour-intensive textile exports (the first unbundling). The question is why this has not yet happened in Africa, which also features access to a large and cheap pool of labour under rapid urbanization, especially as wages rise in Asia.

Asia has clearly been most successful in tapping into the opportunities offered by globalization. For example, China has created special economic zones to attract foreign companies. Singapore has enhanced its strategic location by giving companies significant tax breaks for periods of up to ten years, and the Chinese regions have invested heavily in infrastructure to facilitate exportoriented production. The regions with most inward FDI are all situated on the East coast of China around ports or close to existing agglomerations such as Hong Kong and Taiwan. Local governments have competed for FDI by preferential policies, simplification of bureaucracy, land-use concessions and tax holidays (Zhao and Zhang, 2007). All these factors lower the cost of doing business.

But why are not all cities able to tap into the flows of trade made possible by globalization? Not all fast urbanizing regions of Africa have enjoyed export-led growth even if they are not landlocked and have reasonably good institutions. One reason for this disappointing African performance may be that the costs of agglomeration exceed the benefits. The government-led designation of certain areas for inward FDI in Asia may also have boosted increasing returns to scale,

\footnotetext{
${ }^{2}$ However, the recent growth of China and India has created massive demand for resources and renewed interest in Africa, which has many resource abundant countries. Resource-related FDI towards Africa may now originate mostly from these fast growing countries.
} 
because it directed FDI to a few locations with clearly defined benefits. This policy crucially depends on a strong and dedicated government. Corruption and political strife and instability may make these policies much more difficult to implement in other regions and make it more difficult to persuade foreign companies to invest. A second explanation may be that cities in general only provide more benefits than costs if they are not too large to begin with. We explore this in the next two sections.

\section{II.3. Increasing Returns, Congestion, Migration and City Formation}

Although urbanization in developing countries, such as in much of Asia, can be viewed as an essential part of globalization, it often goes together with problems of congestion, pollution and slums. In African and sometimes also in Latin America, urbanization has often not yielded the growth and employment advantages possible of urbanization (see our discussion of Tables 5-10 in Section III.4). Becker and Morrison (1988) already pointed out that rapid urbanization in Africa has by itself not kick-started many of the conventional engines of growth. One reason may be that, typically, most urbanization is concentrated in one single city, most often a national capital and seat of government. There are reasons why this may lead to inefficiencies and even prevent cities from economically reaching their potential. Even if there is a levelling global playing field between cities, it need not mean that the playing field is levelling inside cities. While ease of international trade has made the world smaller (or 'flatter'), we also see that there are large local spikes: mega-cities have developed alongside globalization.

The degree to which the urban population is concentrated in one city is referred to as primacy (Davis and Henderson, 2003). Section I.2 already described the degree of primacy in the less developed regions of the world such as Latin America and Africa. It manifests itself in cities of over 10 million inhabitants, where people live in very high density and often in poor conditions. This would not be a problem if infrastructure and labour and housing markets could keep up with the fast pace of migration to these cities. London and Paris, for example, are well-functioning cities compared to Nairobi, Mumbai and Dhaka, where most people live in slums, work in the informal sector and lack even the most basic public infrastructure. Here we discuss why mega-cities can lead to the opposite of a level playing field for its inhabitants and how these factors are worse in developing countries. We make use of the diagrammatic exposition presented in Duranton (2007), which itself is based on the model developed by Black and Henderson (1999).

Cities everywhere in the world have a natural tendency to be too large, since cities are riddled with market imperfections. These imperfections entail both the reasons for cities' success and very existence and the reasons why they are less efficient than theoretically possible. For example, local learning spill-overs may not be translated into private wages. Specialist producers are attracted to larger cities because there they can find a larger market, but they are not rewarded for increasing the choice of inputs. Firms are not compensated for their effects on the efficiency of the local labour 
market, nor penalized for their effect on land prices. These type of externalities imply that the marginal returns for every extra agglomerating worker or firm are usually not the same as the marginal returns for the city as a whole. Cumulative causation of the Krugman (1991) variety leads to agglomeration, but may not be beneficial for incumbents even if they are for the new entrant.

Cities may be attractive for potential migrants, but at the same time may be already too large for current inhabitants. Figure 2 illustrates this point. People move to a city in the hope of finding work and improving their real wage, as is happening in China today and has caused the rapid urbanization in Asia in the last decades. Their benchmark is the expected real wage they can obtain outside the city, either in the rural sector if most of the country is still rural or in another city's wage if urbanization has already reached high levels. This corresponds to the flat labour supply curve (see panel (c) in Figure 2), that is the reservation wage (i.e., the net rural wage) is independent of the destination city's population size if mobility is perfect. It may slope upwards or even be vertical if mobility is restricted or costly. The net wage in the destination city $w-H$ consists of the urban wage $w(N)$ offered by firms minus the urban cost of living $H(N)$, both of which are increasing in the city's population $N$. The urban wage is increasing in the size of the population due to agglomeration effects and its overall level depends on productivity-enhancing infrastructure and institutions (panel (a) in Figure 2). The urban cost of living is increasing in the size of the population due to congestion costs such as commuting, housing and through the latter also consumption costs (see panel (b) in Figure 2). Its level depends on, for example, poorly defined property rights which decrease housing investment, and the level of public good provision. The graph is also relevant from a firm's perspective. If we think of firms employing one worker each ("worker-firms"), as assumed in the underlying stylized model of Black and Henderson (1999), it follows that the cost of doing business (the firm equivalent to cost of living for workers) is increasing in the firm-size of the city due to crowding of, for example, shared infrastructure.

The point is that agglomeration forces dominate up to some city size level and increase the net urban wage in panel (c), because without them cities would not exist. At some point B cost of living forces will come to dominate after which the net urban wage decreases eventually and thus constrains the growth of cities. The net wage curve is then bell shaped in the size of the population. A stable equilibrium between net urban wages and the reservation wage exists at point $C$ where the net urban wage intersects the reservation wage from above. No one will leave the city at that point, because that would raise the net urban wage and induce migrants to come back from the countryside. No one would join the city either at point $C$, because the urban cost of living would decrease the net urban wage below the reservation wage and induce migration out of the city back to the countryside. This point is to the right of the peak in the net urban wage (i.e., at point $B$ ). Even if cost-of-living forces become stronger than agglomeration forces, we still have that the net urban wage is higher than the outside option which induces migration towards the city. At the equilibrium city size $C$ firms and workers are indifferent between the crowded city and the country side, which is clearly suboptimal. The other 
equilibrium to the left of the peak (point $A$ ) in net wage is not stable, because every extra migrant to the city will raise urban wages more than the cost of living and so agglomeration forces are strong enough. Conversely, every migrant leaving the city will reduce urban wages more than the urban cost of living, thus inducing even more migration out of the city. Table 5 shows that GDP per capita in cities is quite a bit higher than national GDP per capita, especially in developing countries, but these figures are not corrected for local (urban) cost of living. Income inequality in developing countries and the high share of informal employment makes these estimates moreover imprecise (UN Habitat II survey, 1993).

There exists also a critical minimum city size defined by being large enough for agglomeration forces to overcome the outside rural wage and the local cost of living or cost of doing business. In terms of Figure 2 the critical minimum city size corresponds to point $A$. This size can never be reached by a single person or firm and requires a coordinated group action. This does not happen spontaneously and therefore people tend to cluster in too few cities, which are therefore too large, rather than building new cities. In Figure 2 this is depicted by a population size $N_{C}$, which is larger than the optimal size $N_{B}$. (and, of course, large than the critical minimum city size). A necessary condition for only one equilibrium to exist, at the peak in the net urban wage, is a high enough reservation wage. This, however, requires full urbanization and all cities to be of exactly optimal size. This would correspond to a fully efficient urban system. More important, it requires that cities outside the metropolis reach a certain critical minimum size, for otherwise a train of immigration would never be set in motion. This situation is, however, not the reality in developing countries and therefore people from the countryside all end up going towards the metropolis. The problem is therefore that the metropolis ends up too large from a social point of view with too much congestion, pollution and slums. At the same time, the surrounding cities end up too small to attract migrants from rural areas and thus do not grow or contract. The policy used by many South-East Asian countries of creating several special economic zones (e.g., with more economic freedom and tax breaks) in different locations may have overcome the coordination failure by directing FDI to designated areas. Because there were several areas for firms to choose from, it created policy competition and increasingly favourable terms for foreign firms. Once a critical mass of firms was attracted, the process may have taken off from there, but may never have happened without the initial preferential treatment to attract several firms at once. These local effects can avoid the curse of oversized mega-cities. It makes a balanced urbanization response to globalization possible and could clearly play a big role.

\section{II.4. Over-Sized Cities Induce an Uneven Playing Field}

In order to understand the process of too rapid urbanization and globalization better, it is useful to consider several policy effects that can cause primacy and increase the size of existing cities beyond the efficient size. First, urban bias may result from trade restrictions that favour the domestic 
manufacturing or services sector. The latter are, typically, urban activities and can artificially raise the urban wage rate. The net urban wage increases and consequently the equilibrium city size increases also (Krugman and Elizondo, 1996). This urban bias may also arise naturally, because cities tend to be located in productivity-enhancing locations (e.g., near access to waterways). Trade liberalization may thus highlight the favourable position of such cities. The trade explanation for primacy may be weak if primate cities are also those cities with natural advantages that would benefit most from free trade in any case (Duranton, 2007). On the other hand, Henderson (2004) argues that urban bias is often directed to capital cities designated to be the preferred location for a government-backed national industry. Because the opportunity costs are often very high in these mega-cities, these industries tend to be non-competitive.

Second, political favouritism can also lead to primacy (Ades and Glaeser, 1995; Nitsch, 2006). Autocratic or unstable governments tend to increase primacy; for example, in an effort to direct resources to the seat of government in order to ensure local support. If states are too weak to redistribute towards the primate city, the political favouritism mechanism may also work through more indirect policies. These include subsidized products and exclusively local access to permits, getting credit, enforcing contracts, etcetera (World Bank, 2005). The result is a higher local urban wage curve and hence a larger city. Davis and Henderson (2003) find that primacy is reduced under a more decentralized government structure, because this gives hinterland cities the autonomy needed to compete with the primate city. Furthermore, such policy competition may help to reduce corruption and its negative effects on FDI inflow. This seems to have happened as a consequence of the successful policies of East-Asian countries.

Third, a dual housing market corresponds to an inefficiency that increases the size of all cities, but aggravates the primacy problem. Cities in developing countries can also be characterized by a clear distinction between formal housing and slums. Table 6 shows that up to three quarters of SubSaharan African urban inhabitants live in slums. Table 7 indicates that mortality rates in African cities are much higher and life expectancy rates are much lower than in cities elsewhere. Literacy and school enrolment rates are also much lower in African cities than in cities in other parts of the globe. In contrast, economic growth in South-East Asia has clearly helped to turn informal settlements into formal housing and to provide basic health care and education for its citizens. Slums are not just a reflection of poverty but also a reflection of poorly defined property rights or exclusionary zoning (Henderson, 2007). The high cost of finding substitutes for the lack of public services may even make squatter settlements expensive, possibly making living too costly. Tables 8 and 9 show that infrastructure provision is much lower in informal settlements, which causes households to spend a disproportionate share of their income on substitutes. Table 10 lends support to this view as Africa, the region with highest shares of informal housing, is the region with highest rent to income shares. A dual housing market creates a duality in the urban cost of living, since housing constraints raise the cost of living. Duranton (2007) assumes that this happens more so for squatters in small cities, and 
more so for formal housing in larger cities when rental costs surpass the extra public service substitution costs in slums, the latter of which is relatively invariant to city size. Cities therefore have two urban cost of living curves which intersect, one for each type of housing. While housing constraints were aimed to limit city size (lower net urban wage through higher cost of living for given labour supply), they have the effect that cities grow with slums. After the point where formal cost of living surpasses slum cost of living, the squatter settlements remain relatively affordable and population increases. This assumes, of course, that slum dwellers also benefit from the agglomeration effects. This is likely, because the formal and informal employment sectors are often interlinked through supply-chain links from individuals to smaller firms to larger firms. Table 10 lends some support to the high cost of living in cities in developing countries, because the share of rents in income is especially high in these countries.

An opportunity linked with urbanization is the increase in the share of people with better access to finance than can typically be found in the countryside. The snag is, however, that crowding occurs easily if duality limits access to those few people with formal employment and formal housing. Only these urban residents with collateral have repayment credibility. Slum upgrading and land titles are ways to give informal residents collateral which they can use for loans. Except that this is likely to induce more migration. Cities which have grown to over-sized proportions without meaningful economic growth can thus easily stifle entrepreneurship through its detrimental effect on financing opportunities. $^{3}$

Apart from a dual housing market, urbanization is often characterized by dual labour markets, which prompted the famous and influential contribution of Harris and Todaro (1970). An artificially high (minimum) wage in the urban formal sector above the reservation (rural) wage induces ruralurban migration. The migration into the cities lowers the net expected urban wage until it hits the reservation wage, so that high urban unemployment is an inevitable component of migration induced by high urban wages (e.g., due to efficiency wages or trade unions). This is often used as an argument to restrict migration. However, from a welfare and efficiency point of view, the problem is not migration but wage rigidity (Lall, Selod and Shalizi, 2006; Duranton, 2007).

\footnotetext{
${ }^{3}$ For example, positive effects of land ownership on access to credit and farm productivity have been established. See for example Udry (1999), Reardon et al. (1994) and Binswanger et al. (1995).
} 


\section{PART III: WRAPPING UP}

\section{III.1. Policies for Balanced Urbanization Under Increasing Globalization}

We are now ready to discuss some policy recommendations based on the discussion of part I on globalization and outsourcing and of part II on the process of rapid urbanization paying special attention to developing countries. Part I suggests that it is much more difficult to identify and predict the losers of globalization. The losers are no longer all in one sector or even in one firm, since outshoring, offshoring, etcetera nowadays take place task by task. The codifiable and mundane tasks are most at risk. It thus does not make sense to have industrial policies directed at specific firms or sectors. Even less appropriate are import substitution strategies. Although some of these policies may have worked for the Asian Tigers in the fifties and sixties during the first wave of globalization, they are inappropriate for the current wave of globalization. It does make sense to design policies directed at permanent employment to ensure that the workforce can adapt to a rapidly changing world. The point is that it is difficult to predict where the jobs of the future will be, so the government should direct its education and re-education policies at development of general skills. Rodrik (1997) argues that markets and the state are complementary. Social policies do not necessarily harm the economy unlike what is argued by proponents of the 'Washington consensus'. The maintenance of social safety nets is not a luxury but an essential ingredient of a market economy - e.g., Boadway et al. (2004) and Blanchard and Tirole (2004). Globalization and digitalization produce many benefits, but they also make life riskier and more insecure for many people. A reliable welfare state thus contributes to a proper functioning of the market economy. Rodrik (1998) shows that countries that are more exposed to the risks of international trade have bigger governments, possibly because governments offer social insurance to cushion the effects of exposure to external risk.

De Grauwe and Polan (2002) show that countries that spend most on social security rank highest, on average, in the competitiveness leagues of Lausanne's IMD or of the World Economic Forum. Causation is thus unlikely to run the other way round, so that the reverse link going from strong competitiveness to a stronger economy and more funds for the welfare state is weak. In his path-breaking historical cross-country study Lindert (2004) also argues that there is almost no evidence of a negative effect of a substantial welfare state on gross domestic product. An important reason is that governments become more efficient when distortions resulting from high tax rates are substantial. Countries with large welfare states tend to have a more pro-growth and a regressive mix of taxes (e.g., high taxes on vices and low taxes on capital income). Another reason is that the unemployment caused by generous welfare states are, typically, less productive and thus the harm to national income is limited. A more fundamental reason is that the various distortions of the welfare state tend to cancel each other out so that the burden of the welfare state is much less than simply 
adding up all the distortions one at a time. The general picture that emerges from cross-country evidence is that 'laisser faire' advocates have something to explain. Part I made clear that globalization produces more inequality between incomes of skilled and unskilled workers, so support for growthenhancing policies requires a reliable welfare state to produce more equitable outcomes.

The main conclusions of Part II are that globalization and rapid urbanization go hand in hand and that many of the mega-cities are too large and have too many slums and congestion problems. Policies are thus called for to realize balanced urbanization to ensure development of a variety of cities and avoid urban primacy. The prevalence of primacy across developing countries is a sign that many countries still have significant market distortions. This creates literally an uneven playing field both between and within cities. Most of the causes are only indirectly affected by globalization and beg for better local and national policies. However, globalization may provide a strong argument to deal with these inefficiencies because the opportunities are sizeable. If smaller cities can be helped to grow towards larger cities and primacy can be curtailed, more countries could be induced to participate in the global economy. Rodrik's (2004) cost discovery process can then have a better chance and allow more cities to discover their particular comparative advantage and to convince foreign firms to invest.

One idea for an appropriate policy response is based on the idea that improvement of infrastructure between cities within a country and therefore lower transportation costs affects the size distribution of cities, along the lines predicted by the New Economic Geography literature (Krugman, 1991; Fujita, Krugman and Venables, 1999; Brakman, Garretsen and Marrewijk, 2001; Baldwin et al, 2003). High transportation costs between cities, as is typical in many developing countries, lead to a home bias effect within the country. Manufacturers are locally insulated from import competition, which gives them the market power to ask higher prices and pay a higher wage. They sell mostly at home, since varieties are expensive to export. An increase in manufacturing leads to a larger local market, but also to crowding of sales. The net effect is lower urban wages. The opposing force is agglomeration economies, which eventually dominate as the city increases in size. The urban wage thus initially declines and later increases with city size. The same happens to the urban cost of living curve, because a small city needs to import a lot at high prices whereas a larger city can produce more at home at lower prices. However, eventually increased rents will come to dominate in large cities. The result is a stable small equilibrium city size, and a stable large city size. A decrease in transportation costs makes the urban wage and urban cost of living curves flatter. For firms it can mean more competition, but it also generates more opportunity for exports (a larger market). The latter makes cost of living in small cities lower. Duranton (2007) suggests that on balance the net urban wage increases in small cities. This can induce cities that pass the critical minimum size to grow towards large cities.

Another idea for an appropriate policy response is concerned with developing the stock of human capital. Growth of cities, both of existing and new cities, depends on human capital 
(Henderson, 2003). Growth of cities also depends on the externalities generated by the concentration of human capital and by own industry localization economies (specialization). There is no reason to believe that the underlying foundations should be different in developing countries. Lall, Selod and Shalizi (2006) review recent developing country evidence of the effects of migration on migrants themselves, but also on the destination economy (typically a city). The empirical evidence suggests that the earnings of migrants is lower upon entry in a developing country's city, but converges over time. This process is faster and starts from a higher level if the migrant is higher educated, which indicates that there are returns to education in cities. Networks facilitate the matching process, but can also lead to crowding as the local immigrant size from a particular origin region increases. Nonetheless, the prospect of better paid employment in urban areas appears to increase the probability of educational attainment in rural areas. Furthermore, a significant share of migrants' wages is remitted to the region of origin. Although the departure of rural migrants to the cities can lower rural area production in the short run, in the long run the remittances fuel rural yields because part is invested locally. There is also evidence that the above effects diminish with distance. On the one hand, this can mean that primacy is a large enough pull factor to overcome distance. On the other hand, the growth of multiple urban centres can be much more efficient if it can induce more people to get an education. It is essential that cities of all sizes encourage the accumulation of human capital. One way to aid this process is to increase the business climate that makes acquiring human capital worthwhile. Primate cities that float on preferential treatment and corruption hamper the accumulation process, in addition to the suboptimal effects on urban wages.

The various types of imperfections in cities make it hard to label any particular city as being too large. We would, however, tentatively make a distinction between countries with high economic growth such as China and India fuelled by globalization and other countries with low growth and somewhat disconnected from the process of globalization as often seems to be the case in Africa and Latin America. Low growth essentially means that many African and some Latin-American cities are less able to benefit from globalization than their Asian counterparts. If a flat world means equal opportunities then there is clearly a long way to go still, both between and within countries.

\section{III.2. Concluding Remarks}

The waves of globalization caused by technological progress have made it possible to move entire sectors to low-wage countries and outsource production task by task. From that perspective far-away locations are a lot closer than they used to be. This is the international dimension. However, we have argued that this coincides with an increased importance for the local dimension: agglomerations and cities. Production and people still cluster in a few places, and increasingly in very large and often too large cities. Globalization has opened up many opportunities for all cities in the world to discover their particular comparative advantage and attract its share of global trade. Thomas Friedman has argued 
that "In a flat world, everything that can be done, will be done. The only question is: Are you going to do it, or is somebody else going to do it to you?". "Somebody else” is not just anybody and might actually be your neighbour in the same city. But this is not a bad thing. The increasing returns associated with agglomerations can make everyone more productive provided that they outweigh the crowding and negative externalities. Productivity returns increase in the scale of agglomerations and give city residents the means to compete on a world scale. This is an argument to curtail urban primacy with all its manifest market failures and let the ongoing rapid urbanization create more cities. Government policy is crucial for removing the inefficient policies that lead to primacy and directing public resources to efficient policies which enhance agglomeration effects, such as education, infrastructure and a competitive business climate open to entrepreneurship. Urbanization, provided the resulting cities do not become too large and too few, is an essential ingredient to be able to compete in the global arena. In this sense, the world is not flat.

\section{REFERENCES}

Ades, A.F. and E.L. Glaeser (1995). Trade and circuses: Explaining urban giants, Quarterly Journal of Economics, 110(1):195-227.

$\mathrm{Au}$, Ch.-Ch. and J.V. Henderson (2006a). How migration restrictions limit agglomeration and productivity in China, Journal of Development Economics, 80(2), 350-388.

Au, Ch.-Ch. and J.V. Henderson (2006b). Are Chinese cities too small?, Review of Economic Studies, 73(3), 549-576.

Baldwin, R.E. (2006). Globalisation: the great unbundling(s), Economic Council of Finland, Helsinki.

Baldwin, R.E. and P. Martin (1999). Two waves of globalisation: superficial similarities and fundamental differences, chapter 1, 3-29 in H. Giersch (ed.), Globalisation and Labour, J.C.B. Mohr for Kiel World Institute of World Economics, Tübingen.

Baldwin, R.E., R. Forslid, P. Martin, G. Ottavanio and F. Robert (2003). Economic Geography and Public Policy, Princeton University Press, Princeton, New Jersey.

Barbier, E.B. (2006). Natural Resources and Economic Development, Cambridge University Press, Cambridge, UK.

Becker, C.M. and A.R. Morrison (1988). The determinants of urban population growth in Sub-Saharan Africa, Economic Development and Cultural Change, 259-278.

Bhagwati, J. (2004). In Defense of Globalization, Oxford University Press, Oxford.

Binswanger, H.P., K. Deininger and G. Feder (1995). Power, distortions, revolt and reform in agricultural land relations, Chapter 42, 2659-2772, in J. Behrman and T.N. Srinivasan (eds.), Handbook of Development Economics, Volume 3B, North-Holland, Amsterdam. 
Birdsall, N. (2005). The World is not Flat: inequality and injustice in our global economy, WIDER Annual Lecture 9, UNU World Institute for Development Economics Research, Helsinki.

Black, D. and J.V. Henderson (1999). A theory of urban growth, " Journal of Political Economy, $107,252-84$.

Blinder, A.S. (2006). Offshoring: the next industrial revolution?, Foreign Affairs, 85 (2), 113-128.

Blum, B.S. and A. Goldfarb (2006). Does the Internet defy the law of gravity?, Journal of International Economics, 70(2), 384-405.

Blanchard, O. and J. Tirole (2004). The optimal design of unemployment insurance and employment protection, A first pass, NBER Working Paper 10443, Cambridge, Mass.

Boadway, R., M. Leite-Monteiro, M.G. Marchand and P. Piestieau (2004). Social insurance and redistribution with moral hazard and adverse selection, Discussion Paper No. 4253, CEPR, London.

Brakman, S., H. Garretsen and C. van Marrewijk (2001). An Introduction to Geographical Economics, Cambridge University Press, Cambridge, U.K.

Christaller, W. (1933). Die Zentralen Orte in Suddeutschland, Gustav/Fischer, Jena.

Combes, P-P., Duranton, G. (2006). Labour pooling, labour poaching, and spatial clustering, Regional Science and Urban Economics, 36(1), 1-28.

Davis, J.C. and J.V. Henderson (2003). Evidence on the political economy of the urbanization process, Journal of Urban Economics, 53, 98-125.

Disdier, A-C. and K. Head (2008). The Puzzling Persistence of the Distance Effect on Bilateral Trade, Review of Economics and Statistics, forthcoming.

Duranton, G. (2007). From cities to growth in developing countries, Discussion Paper No. 6634, CEPR, London.

Duranton, Gilles and D. Puga (2001). Nursery cities: urban diversity, process innovation, and the life cycle of products, American Economic Review, 91(5), 1454-1477.

Duranton, G. and D. Puga (2004). Micro foundations of urban agglomeration economies, in V. Henderson and J. Thisse (eds.), Handbook of Regional and Urban Economics, Vol. 4., NorthHolland, Amsterdam.

Fay, M. and C. Opal (2000). Urbanization without growth: a not so uncommon phenomenon, Working Paper No. 2412, World Bank, Washington, D.C.

Florida, R. (2005). Cities and the Creative Class, Routledge, Abingdon, UK.

Friedman, T.L. (2007). The World is Flat, The Globalized World in the Twenty-First Century, third edition, Penguin Books, London.

Fujita, M., P. Krugman and A.J. Venables (1999). The Spatial Economy, Cities, Regions, and International Trade, MIT Press, Cambridge, Mass.

Geishecker, I. and H. Görg (2007). Winners and losers: a micro-level analysis of international outsourcing and wages, Discussion Paper No. 6484, CEPR, London. 
Glaeser, E.L. and J.E. Kohlhase (2004). Cities, regions and the decline of transport costs, Papers in Regional Science, 83, 197-228.

Grauwe, P. and M. Polan (2002). Globalisation and social security. A race to the bottom?, University of Leuven.

Grossman, G. and E. Rossi-Hansberg (2006). The rise of offshoring: it's not wine for cloth anymore, Princeton University, Princeton, New Jersey.

Harris, J.R. and M.P. Todaro (1970). Migration, unemployment and development: a two-sector analysis, American Economic Review, 60(1), 126-142.

Hausmann, R. and D. Rodrik. (2002). Economic development as self-discovery, Working Paper No. 8952, NBER, Cambridge, Mass.

Henderson, J.V. (2003). The Urbanization process and economic growth: the so-what question, Journal of Economic Growth, 8, 47-71.

Henderson, J.V. (2004). Urbanization and growth, in P. Aghion and S. Durlauf (eds.), Handbook of Economic Growth, North-Holland, Amsterdam.

Henderson, J. V. (2007). Exclusion through informal sector housing development, Brown University.

Hsiao C. and Y. Shen (2003). Foreign direct investment and economic growth: the importance of institutions and urbanization, Economic Development and Cultural Change, 883-896.

Hummel, D. (2008). Transportation Costs and International Trade Over Time, Journal of Economic Perspectives, forthcoming.

Krugman, P.R. (1980). Scale economies, product differentiation, and the pattern of trade, American Economic Review, 70, 950-959.

Krugman, P.R. (1991). Increasing returns and economic geography, Journal of Political Economy, 99(3), 484-499.

Krugman, P.R. and R.L. Elizondo (1996). Trade policy and the Third World metropolis, Journal of Development Economics, 49(1), 137-150.

Lall, S.V., H. Selod, and Z. Shalizi. 2006. Rural-urban migration in developing countries: A survey of theoretical predictions and empirical findings. Policy Research Working Paper No. 3915, World Bank, Washington, D.C.

Leamer, E.E. (2007). A flat world, a level playing field, a small world after all, or none of the above? A review of Thomas L. Friedman The World is Flat, Journal of Economic Literature, XLV, 83-126.

Lindert, P.H. (2004). Growing Public - Social Spending and Economic Growth Since the Eighteenth Century, Cambridge University Press, Cambridge, U.K.

Losch, A. (1938). The nature of economic regions, Southern Economic Journal, 5, 1, 71-78.

Lucas, R.E. (2004). Life earnings and rural-urban migration, Journal of Political Economy 112, 29-59.

Nitsch, V. (2006). Trade openness and urban concentration: new evidence, Journal of Economic Integration, 21(2), 340-362. 
Noorbakhsh, F., A. Paloni and A. Youssef (2001). Human capital and FDI inflows to developing countries: new empirical evidence, World Development, 29, 1593-1610.

Overman, H.G. and Venables, A.J. (2005). Cities in the developing world, CEP Discussion Paper No. 695, LSE, London.

Reardon, K., E. Crawford and V. Kelly (1994). Links between nonfarm income and farm investment in African households: adding the capital market perspective, American Journal of Agricultural Economics, 76, 1172-1176.

Rodrik, D. (1997). The 'paradoxes' of the successful state, European Economic Review, 41, 3-5, 411442.

Rodrik, D. (1998). Why do open economies have bigger governments?, Journal of Political Economy, 106, 997-1032.

Rodrik, D. (2004). Industrial policy for the twenty-first century, Discussion Paper No. 4767, CEPR, London.

Standage, T. (1998). The Victorian Internet: The Remarkable Story of the Telegraph and the Nineteenth Century's Online Pioneers, Walker and Company, New York.

Stiglitz, J. (1976). The efficiency wage hypothesis, surplus labour and the distribution of income in L.D.C.'s, Oxford Economic Papers, 28, 185-207.

Storper, M. and A.J. Venables (2004). Buzz: face-to-face contact and the urban economy, Journal of Economic Geography, 4, 351-370.

Udry, C. (1999). Efficiency and market structure: testing for profit maximization in African agriculture, in G. Ranis and L.K. Raut (eds.), Trade, Growth and Development, NorthHolland, Amsterdam.

United Nations (2003). UN-HABITAT, Urban indicators, New York. Webpage: ww2.unhabitat.org/programmes/guo/urban_indicators.asp.

United Nations (2006). World Urbanization Prospects: The 2005 Revision, New York.

Williamson, J. (1965). Regional inequality and the process of national development, Economic Development and Cultural Change, June, 3-45.

World Bank (2005). Doing Business in 2005: Removing Obstacles to Growth. A co-publication of the World Bank, the International Finance Corporation and Oxford University Press.

Zhao, S.X.B., Zhang, L., (2007). Foreign direct investment and the formation of global city-regions in China, Regional Studies, Vol. 41(7), 979-994. 


\section{Figure 1: Urbanization and growth}

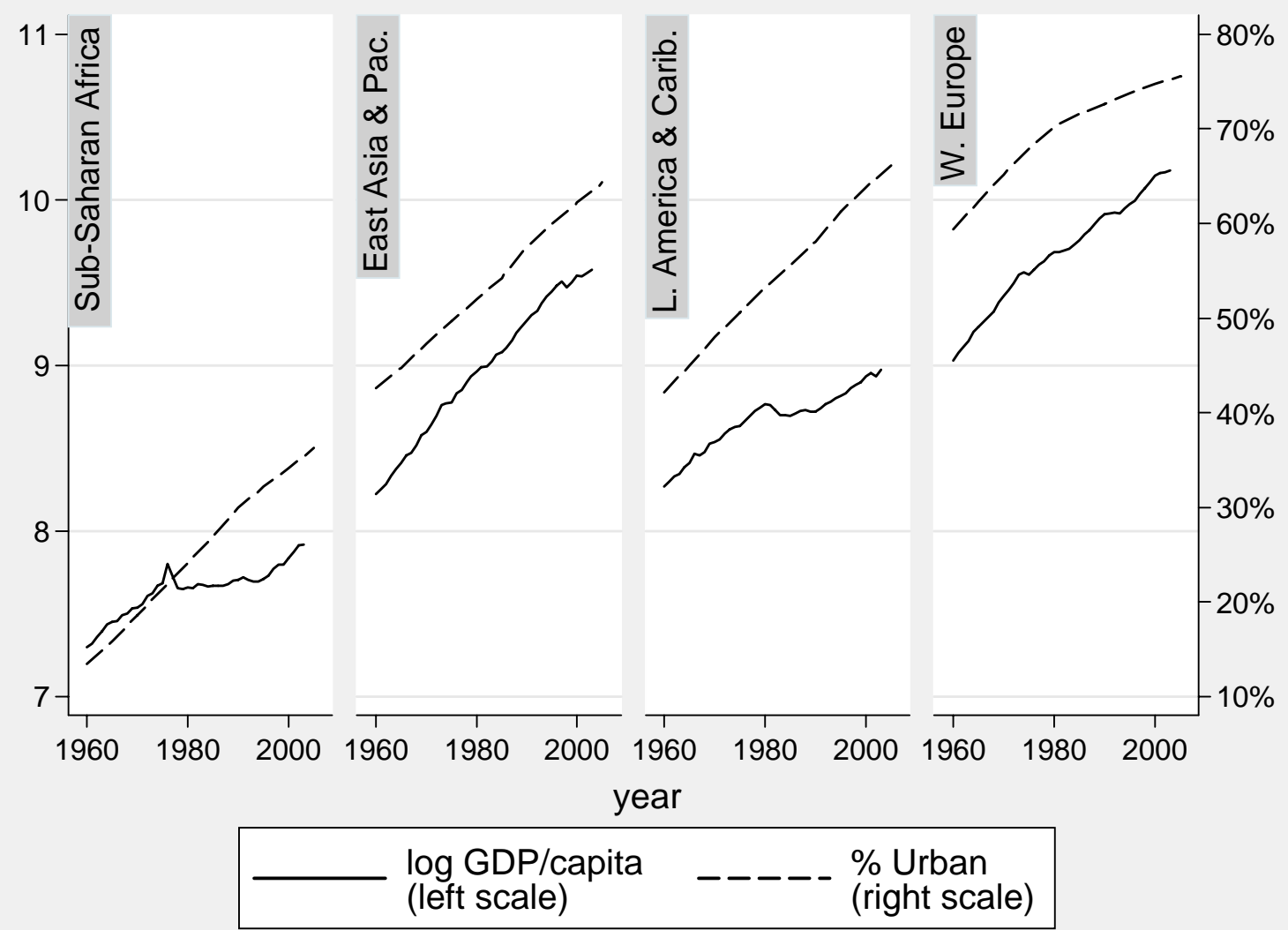

Source: United Nations (2006) and PWT6.2, Penn World Table (2005).

Table 1: Urban population as percentage of total population, by region

\begin{tabular}{lrrrrrrrrr}
\hline \hline & 1950 & 1960 & 1970 & 1980 & 1990 & 2000 & 2010 & 2020 & 2030 \\
\hline World & 29.0 & 32.8 & 35.9 & 39.1 & 43.0 & 46.7 & 50.8 & 55.1 & 59.9 \\
\hline Africa & 14.7 & 18.7 & 23.4 & 27.6 & 32.0 & 36.2 & 40.5 & 45.3 & 50.7 \\
Asia & 16.8 & 19.9 & 22.7 & 26.3 & 31.9 & 37.1 & 42.5 & 48.1 & 54.1 \\
$\begin{array}{l}\text { Latin America and } \\
\text { the Caribbean }\end{array}$ & 42.0 & 49.2 & 57.2 & 65.1 & 70.9 & 75.4 & 79.1 & 81.9 & 84.3 \\
$\begin{array}{l}\text { Europe } \\
\text { Northern America }\end{array}$ & 50.5 & 56.5 & 62.6 & 67.9 & 70.6 & 71.7 & 72.9 & 75.1 & 78.3 \\
Oceania & 62.0 & 69.9 & 73.8 & 73.9 & 75.4 & 79.1 & 82.1 & 84.6 & 86.7 \\
\hline Sola & 66.6 & 70.8 & 71.2 & 70.3 & 70.5 & 71.2 & 72.3 & 73.8 \\
\hline
\end{tabular}

Source: United Nations (2006) 
Figure 2: Increasing returns, congestion, migration and city formation

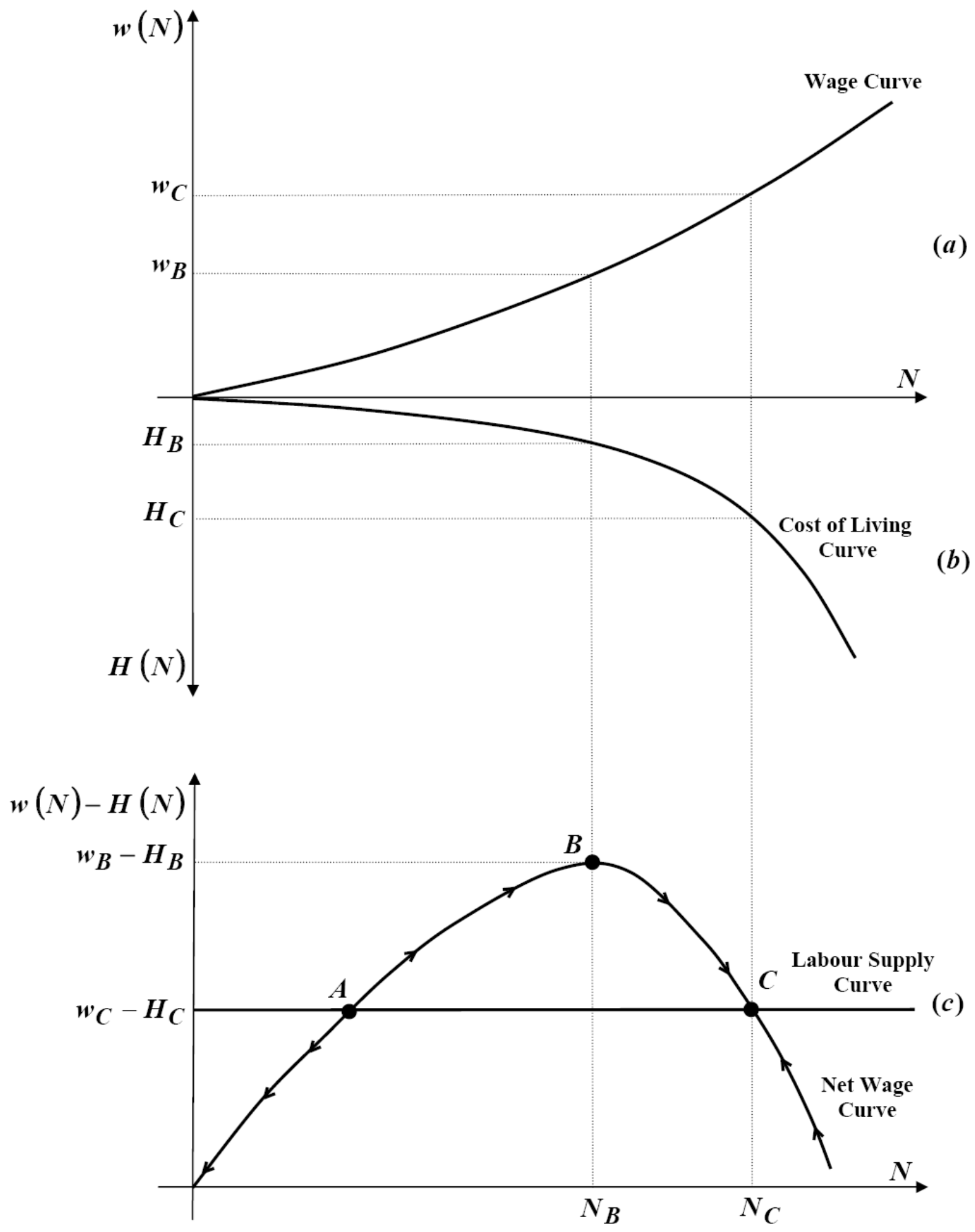

Key: N, w and H denote city size, urban wage and urban cost of living, respectively. Points A, B and $\mathrm{C}$ correspond to the critical minimum city size, optimal city size and too large inefficient city size, respectively. At A and $\mathrm{C}$ the net urban wage is driven to the reservation (rural) wage.

Source: Duranton (2007, p. 5) 
Table 2: Population of a country's largest city as percentage of total urban population

\begin{tabular}{lllllllll}
\hline \hline Average by region: & 1960 & 1965 & 1970 & 1975 & 1980 & 1985 & 1990 & 1995 \\
\hline Latin America \& Caribbean & 38.5 & 38.8 & 39.6 & 39.7 & 39.7 & 40.1 & $\mathbf{4 0 . 4}$ & 40.3 \\
Sub-Saharan Africa & 33.7 & 34.9 & 36.4 & 36.3 & 35.7 & 36.3 & 37.8 & $\mathbf{3 9 . 5}$ \\
East Asia \& Pacific & 38.0 & 38.7 & 39.0 & $\mathbf{3 9 . 5}$ & 39.4 & 38.3 & 37.0 & 36.0 \\
Middle East \& North Africa & $\mathbf{3 5 . 0}$ & 34.8 & 34.1 & 34.4 & 34.0 & 32.3 & 30.6 & 29.2 \\
Western Europe & $\mathbf{2 7 . 5}$ & 27.0 & 26.5 & 26.0 & 25.8 & 25.5 & 25.5 & 25.3 \\
South Asia & 17.2 & 16.2 & 16.9 & 17.3 & 17.0 & 17.7 & 19.0 & $\mathbf{2 1 . 2}$ \\
Eastern Europe \& Central Asia & 20.8 & 20.5 & 20.3 & $\mathbf{2 0 . 8}$ & 20.5 & 18.8 & 17.9 & 18.6 \\
North America & $\mathbf{1 3 . 6}$ & 13.6 & 13.4 & 12.9 & 12.7 & 12.9 & 13.1 & 13.4 \\
\hline \hline
\end{tabular}

Note: peak in bold. Source: Davis and Henderson (2003)

Table 3: Agglomerations with more than 10 million inhabitants

\begin{tabular}{|c|c|c|c|c|c|c|c|c|c|c|}
\hline \multirow{2}{*}{$\begin{array}{l}1950 \\
\text { Rank City }\end{array}$} & \multicolumn{3}{|c|}{1975} & \multicolumn{3}{|c|}{2000} & \multicolumn{3}{|c|}{2005} & \multirow[b]{2}{*}{$\begin{array}{l}\text { Pop. } \\
\text { Mln }\end{array}$} \\
\hline & $\begin{array}{l}\text { Pop. } \\
\text { Mln }\end{array}$ & Ran & City & $\begin{array}{l}\text { Pop. } \\
\text { Mln }\end{array}$ & Ran & City & $\begin{array}{l}\text { Pop. } \\
\text { Mln }\end{array}$ & Rank & City & \\
\hline 1 New York-Newark & 12.3 & 1 & Tokyo & 26.6 & 1 & Tokyo & 34.4 & 1 & Tokyo & 35.2 \\
\hline \multirow[t]{21}{*}{2 Tokyo } & 11.3 & 2 & New York-Newark & 15.9 & 2 & Mexico City & 18.1 & 2 & Mexico City & 19.4 \\
\hline & & 3 & Mexico City & 10.7 & 3 & New York-Newark & 17.8 & 3 & New York-Newark & 18.7 \\
\hline & & & & & 4 & São Paulo & 17.1 & 4 & São Paulo & 18.3 \\
\hline & & & & & 5 & Mumbai & 16.1 & 5 & Mumbai & 18.2 \\
\hline & & & & & 6 & Shanghai & 13.2 & 6 & Delhi & 15.0 \\
\hline & & & & & 7 & Kolkata & 13.1 & 7 & Shanghai & 14.5 \\
\hline & & & & & 8 & Delhi & 12.4 & 8 & Kolkata & 14.3 \\
\hline & & & & & 9 & Buenos Aires & 11.8 & 9 & Jakarta & 13.2 \\
\hline & & & & & & Angeles-Lor & & & & \\
\hline & & & & & 10 & Beach-Santa Ana & 11.8 & 10 & Buenos Aires & 12.6 \\
\hline & & & & & 11 & Osaka-Kobe & 11.2 & 11 & Dhaka & 12.4 \\
\hline & & & & & & & & & Angeles-Lor & \\
\hline & & & & & 12 & Jakarta & 11.1 & 12 & Beach-Santa Ana & 12.3 \\
\hline & & & & & 13 & Rio de Janeiro & 10.8 & 13 & Karachi & 11.6 \\
\hline & & & & & 14 & Cairo & 10.4 & 14 & Rio de Janeiro & 11.5 \\
\hline & & & & & 15 & Dhaka & 10.2 & 15 & Osaka-Kobe & 11.3 \\
\hline & & & & & 16 & Moscow & 10.1 & 16 & Cairo & 11.1 \\
\hline & & & & & 17 & Karachi & 10.0 & 17 & Lagos & 10.9 \\
\hline & & & & & & Manila & 10.0 & 18 & Beijing & 10.7 \\
\hline & & & & & & & & 19 & Manila & 10.7 \\
\hline & & & & & & & & 20 & Moscow & 10.7 \\
\hline
\end{tabular}

Source: United Nations (2006) 
Table 4: Urban population growth (\%) by level of development and city size

\begin{tabular}{llllllll}
\hline \hline $\begin{array}{l}\text { Less Developed } \\
\text { Regions }\end{array}$ & $75-80$ & $80-85$ & $85-90$ & $90-95$ & $95-00$ & $00-05$ & Average \\
\hline $10 \mathrm{mln}$ or more & 134.8 & 50.8 & 96.4 & 49.1 & 39.1 & 32.5 & 67.1 \\
5 to $10 \mathrm{mln}$ & 45.4 & 22.6 & -5.9 & 7.1 & 25.3 & -1.0 & 15.6 \\
1 to $5 \mathrm{mln}$ & 16.6 & 19.8 & 27.5 & 18.6 & 16.9 & 16.8 & 19.4 \\
$500000-1 \mathrm{mln}$ & 14.8 & 18.5 & 17.2 & 16.2 & 11.2 & 18.7 & 16.1 \\
less than 500 000 & 19.0 & 20.9 & 19.3 & 15.2 & 12.1 & 11.9 & 19.0 \\
\hline & & & & & & & \\
More Developed 75-80 & $80-85$ & $85-90$ & $90-95$ & $95-00$ & $00-05$ & Average \\
Regions & & & & & & & \\
\hline 10 mln or more & 3.9 & 51.0 & 5.8 & 3.4 & 17.1 & 3.2 & 14.1 \\
5 to 10 mln & 3.3 & -36.5 & 17.7 & 3.9 & 4.6 & 29.7 & 3.8 \\
1 to 5 mln & 14.7 & 6.3 & 4.3 & 7.8 & 2.1 & 1.4 & 6.1 \\
500 000 - 1 mln & -6.4 & 8.7 & 2.1 & 1.8 & 1.9 & 3.4 & 1.9 \\
less than 500000 & 6.0 & 4.0 & 4.5 & 2.7 & 1.1 & 0.7 & 3.2 \\
\hline
\end{tabular}

Source: United Nations (2006)

Table 5: Urban and Regional GDP per capita

\begin{tabular}{llcl}
\hline \hline Region & $\begin{array}{l}\text { GDP } \\
\text { Capita }\end{array}$ & per City product & $\begin{array}{l}\text { Informal } \\
\text { employment }\end{array}$ \\
\hline Africa & $\$ 441$ & $\$ 729$ & $54 \%$ \\
Arab States & $\$ 2,752$ & $\$ 3,170$ & $65 \%$ \\
Asia Pacific & $\$ 4,742$ & $\$ 6,182$ & $33 \%$ \\
HIC & $\$ 22,501$ & $\$ 22,103$ & $3 \%$ \\
LAC & $\$ 3,350$ & $\$ 3,226$ & $39 \%$ \\
Transitional & $\$ 2,541$ & $\$ 2,905$ & $21 \%$ \\
\hline
\end{tabular}

Source: United Nations (2003)

Table 6: percentage urban population living in slums

\begin{tabular}{lll}
\hline \hline Sample average by region: & 1990 & 2001 \\
\hline Latin America \& Caribbean & 35.4 & 31.9 \\
Sub-Saharan Africa & 72.3 & 71.9 \\
Middle East \& North Africa & 35.8 & 32.5 \\
East Asia & 41.1 & 36.4 \\
South East Asia & 36.8 & 28.0 \\
South Asia & 63.4 & 59.0 \\
\hline \hline
\end{tabular}

Source: United Nations (2003) 
Table 7: Health and education in cities

\begin{tabular}{lllll}
\hline \hline Region & $\begin{array}{l}\text { Under age 5 } \\
\text { mortality }\end{array}$ & $\begin{array}{l}\text { Life } \\
\text { expectancy }\end{array}$ & Literacy & $\begin{array}{l}\text { Combined } \\
\text { enrolment }\end{array}$ \\
\hline Africa & $14.6 \%$ & 52.7 & $58.8 \%$ & $45.1 \%$ \\
Arab States & $5.7 \%$ & 68.2 & $69.1 \%$ & $57.7 \%$ \\
Asia-Pacific & $4.4 \%$ & 67.4 & $82.5 \%$ & $71.2 \%$ \\
HIC & $0.9 \%$ & 77.6 & $97.6 \%$ & $88.4 \%$ \\
LAC & $3.6 \%$ & 70.9 & $82.1 \%$ & $69.6 \%$ \\
Transitional & $2.4 \%$ & 67.3 & $95.2 \%$ & $79.1 \%$ \\
\hline
\end{tabular}

Source: United Nations (2003)

Table 8: Connections to infrastructure

\begin{tabular}{llllll}
\hline \hline Region & Water $^{1}$ & Sewerage & Electricity & Telephone & $\begin{array}{c}\text { Access to } \\
\text { water }\end{array}$ \\
\hline Africa & $48.4 \%$ & $30.9 \%$ & $53.9 \%$ & $15.5 \%$ & $73.5 \%$ \\
Arab States & $79.1 \%$ & $65.9 \%$ & $91.8 \%$ & $42.0 \%$ & $88.0 \%$ \\
Asia-Pacific & $65.9 \%$ & $58.0 \%$ & $94.4 \%$ & $57.1 \%$ & $94.8 \%$ \\
HIC & $99.6 \%$ & $99.7 \%$ & $100.0 \%$ & $99.5 \%$ & $99.7 \%$ \\
LAC & $83.7 \%$ & $63.5 \%$ & $91.2 \%$ & $51.7 \%$ & $89.1 \%$ \\
Transitional & $91.1 \%$ & $89.6 \%$ & $99.2 \%$ & $73.5 \%$ & $97.3 \%$ \\
\hline
\end{tabular}

Source: United Nations (2003)

Note 1: Water connections refers to percentage of households with a piped water connection. Access to water means having potable water within 200 metres of the household (e.g., standpipes, wells etc), and includes water connections (since most countries presume piped water is potable).

Table 9: Connections to infrastructure - informal settlements

\begin{tabular}{llllll}
\hline \hline Region & Water & Sewerage & Electricity & Telephone & $\begin{array}{c}\text { Access to } \\
\text { water }\end{array}$ \\
\hline Africa & $19.1 \%$ & $7.4 \%$ & $20.3 \%$ & $2.9 \%$ & $40.0 \%$ \\
Arab States & $35.7 \%$ & $21.5 \%$ & $35.9 \%$ & $30.0 \%$ & $42.7 \%$ \\
Asia-Pacific & $38.3 \%$ & $7.4 \%$ & $75.7 \%$ & $25.4 \%$ & $89.1 \%$ \\
LAC & $57.9 \%$ & $30.3 \%$ & $84.7 \%$ & $32.0 \%$ & $66.8 \%$ \\
Transitional & $33.6 \%$ & $28.8 \%$ & $60.7 \%$ & $29.7 \%$ & $57.5 \%$ \\
\hline
\end{tabular}

Source: United Nations (2003)

Table 10: Habitat II survey 1993

\begin{tabular}{lll}
\hline \hline Region & $\begin{array}{c}\text { House price to } \\
\text { income ratio }\end{array}$ & $\begin{array}{c}\text { House Rent to } \\
\text { Income ratio }\end{array}$ \\
\hline Africa & 6.9 & $27.3 \%$ \\
Arab States & 9.7 & $17.8 \%$ \\
Asia Pacific & 9.4 & $23.7 \%$ \\
HIC & 4.4 & $18.9 \%$ \\
LAC & 3.8 & $20.2 \%$ \\
Transitional & 12.2 & $4.4 \%$ \\
\hline \hline
\end{tabular}

Source: United Nations (2003) 


\section{CESifo Working Paper Series}

for full list see www.cesifo-group.org/wp

(address: Poschingerstr. 5, 81679 Munich, Germany, office@cesifo.de)

2144 Kai A. Konrad, Mobile Tax Base as a Global Common, November 2007

2145 Ola Kvaløy and Trond E. Olsen, The Rise of Individual Performance Pay, November 2007

2146 Guglielmo Maria Caporale, Yannis Georgellis, Nicholas Tsitsianis and Ya Ping Yin, Income and Happiness across Europe: Do Reference Values Matter?, November 2007

2147 Dan Anderberg, Tax Credits, Income Support and Partnership Decisions, November 2007

2148 Andreas Irmen and Rainer Klump, Factor Substitution, Income Distribution, and Growth in a Generalized Neoclassical Model, November 2007

2149 Lorenz Blume, Jens Müller and Stefan Voigt, The Economic Effects of Direct Democracy - A First Global Assessment, November 2007

2150 Axel Dreher, Pierre-Guillaume Méon and Friedrich Schneider, The Devil is in the Shadow - Do Institutions Affect Income and Productivity or only Official Income and Official Productivity?, November 2007

2151 Valentina Bosetti, Carlo Carraro, Emanuele Massetti and Massimo Tavoni, International Energy R\&D Spillovers and the Economics of Greenhouse Gas Atmospheric Stabilization, November 2007

2152 Balázs Égert and Dubravko Mihaljek, Determinants of House Prices in Central and Eastern Europe, November 2007

2153 Christa Hainz and Hendrik Hakenes, The Politician and his Banker, November 2007

2154 Josef Falkinger, Distribution and Use of Knowledge under the "Laws of the Web", December 2007

2155 Thorvaldur Gylfason and Eduard Hochreiter, Growing Apart? A Tale of Two Republics: Estonia and Georgia, December 2007

2156 Morris A. Davis and François Ortalo-Magné, Household Expenditures, Wages, Rents, December 2007

2157 Andreas Haufler and Christian Schulte, Merger Policy and Tax Competition, December 2007

2158 Marko Köthenbürger and Panu Poutvaara, Rent Taxation and its Intertemporal Welfare Effects in a Small Open Economy, December 2007 
2159 Betsey Stevenson, Title IX and the Evolution of High School Sports, December 2007

2160 Stergios Skaperdas and Samarth Vaidya, Persuasion as a Contest, December 2007

2161 Morten Bennedsen and Christian Schultz, Arm's Length Provision of Public Services, December 2007

2162 Bas Jacobs, Optimal Redistributive Tax and Education Policies in General Equilibrium, December 2007

2163 Christian Jaag, Christian Keuschnigg and Mirela Keuschnigg, Pension Reform, Retirement and Life-Cycle Unemployment, December 2007

2164 Dieter M. Urban, Terms of Trade, Catch-up, and Home Market Effect: The Example of Japan, December 2007

2165 Marcelo Resende and Rodrigo M. Zeidan, Lionel Robbins: A Methodological Reappraisal, December 2007

2166 Samuel Bentolila, Juan J. Dolado and Juan F. Jimeno, Does Immigration Affect the Phillips Curve? Some Evidence for Spain, December 2007

2167 Rainald Borck, Federalism, Fertility and Growth, December 2007

2168 Erkki Koskela and Jan König, Strategic Outsourcing, Profit Sharing and Equilibrium Unemployment, December 2007

2169 Egil Matsen and Øystein Thøgersen, Habit Formation, Strategic Extremism and Debt Policy, December 2007

2170 Torben M. Andersen and Allan Sørensen, Product Market Integration and Income Taxation: Distortions and Gains from Trade, December 2007

2171 J. Atsu Amegashie, American Idol: Should it be a Singing Contest or a Popularity Contest?, December 2007

2172 Patricia Apps and Ray Rees, Household Models: An Historical Perspective, December 2007

2173 Ben Greiner, Axel Ockenfels and Peter Werner, The Dynamic Interplay of Inequality and Trust - An Experimental Study, December 2007

2174 Michael Melvin and Magali Valero, The Dark Side of International Cross-Listing: Effects on Rival Firms at Home, December 2007

2175 Gebhard Flaig and Horst Rottmann, Labour Market Institutions and the Employment Intensity of Output Growth. An International Comparison, December 2007

2176 Alexander Chudik and M. Hashem Pesaran, Infinite Dimensional VARs and Factor Models, December 2007 
2177 Christoph Moser and Axel Dreher, Do Markets Care about Central Bank Governor Changes? Evidence from Emerging Markets, December 2007

2178 Alessandra Sgobbi and Carlo Carraro, A Stochastic Multiple Players Multi-Issues Bargaining Model for the Piave River Basin, December 2007

2179 Christa Hainz, Creditor Passivity: The Effects of Bank Competition and Institutions on the Strategic Use of Bankruptcy Filings, December 2007

2180 Emilia Del Bono, Andrea Weber and Rudolf Winter-Ebmer, Clash of Career and Family: Fertility Decisions after Job Displacement, January 2008

2181 Harald Badinger and Peter Egger, Intra- and Inter-Industry Productivity Spillovers in OECD Manufacturing: A Spatial Econometric Perspective, January 2008

2182 María del Carmen Boado-Penas, Salvador Valdés-Prieto and Carlos Vidal-Meliá, the Actuarial Balance Sheet for Pay-As-You-Go Finance: Solvency Indicators for Spain and Sweden, January 2008

2183 Assar Lindbeck, Economic-Social Interaction in China, January 2008

2184 Pierre Dubois, Bruno Jullien and Thierry Magnac, Formal and Informal Risk Sharing in LDCs: Theory and Empirical Evidence, January 2008

2185 Roel M. W. J. Beetsma, Ward E. Romp and Siert J. Vos, Intergenerational Risk Sharing, Pensions and Endogenous Labor Supply in General Equilibrium, January 2008

2186 Lans Bovenberg and Coen Teulings, Rhineland Exit?, January 2008

2187 Wolfgang Leininger and Axel Ockenfels, The Penalty-Duel and Institutional Design: Is there a Neeskens-Effect?, January 2008

2188 Sándor Csengődi and Dieter M. Urban, Foreign Takeovers and Wage Dispersion in Hungary, January 2008

2189 Joerg Baten and Andreas Böhm, Trends of Children's Height and Parental Unemployment: A Large-Scale Anthropometric Study on Eastern Germany, 1994 2006, January 2008

2190 Chris van Klaveren, Bernard van Praag and Henriette Maassen van den Brink, A Public Good Version of the Collective Household Model: An Empirical Approach with an Application to British Household Data, January 2008

2191 Harry Garretsen and Jolanda Peeters, FDI and the Relevance of Spatial Linkages: Do third Country Effects Matter for Dutch FDI?, January 2008

2192 Jan Bouckaert, Hans Degryse and Theon van Dijk, Price Discrimination Bans on Dominant Firms, January 2008 
2193 M. Hashem Pesaran, L. Vanessa Smith and Takashi Yamagata, Panel Unit Root Tests in the Presence of a Multifactor Error Structure, January 2008

2194 Tomer Blumkin, Bradley J. Ruffle and Yosef Ganun, Are Income and Consumption Taxes ever really Equivalent? Evidence from a Real-Effort Experiment with Real Goods, January 2008

2195 Mika Widgrén, The Impact of Council's Internal Decision-Making Rules on the Future EU, January 2008

2196 Antonis Adam, Margarita Katsimi and Thomas Moutos, Inequality and the Import Demand Function, January 2008

2197 Helmut Seitz, Democratic Participation and the Size of Regions: An Empirical Study Using Data on German Counties, January 2008

2198 Theresa Fahrenberger and Hans Gersbach, Minority Voting and Long-term Decisions, January 2008

2199 Chiara Dalle Nogare and Roberto Ricciuti, Term Limits: Do they really Affect Fiscal Policy Choices?, January 2008

2200 Andreas Bühn and Friedrich Schneider, MIMIC Models, Cointegration and Error Correction: An Application to the French Shadow Economy, January 2008

2201 Seppo Kari, Hanna Karikallio and Jukka Pirttilä, Anticipating Tax Change: Evidence from the Finnish Corporate Income Tax Reform of 2005, January 2008

2202 Walter Krämer and André Güttler, On Comparing the Accuracy of Default Predictions in the Rating Industry, January 2008

2203 Syed M. Ahsan and Panagiotis Tsigaris, The Efficiency Loss of Capital Income Taxation under Imperfect Loss Offset Provisions, January 2008

2204 P. Mohnen, F. C. Palm, S. Schim van der Loeff and A. Tiwari, Financial Constraints and other Obstacles: Are they a Threat to Innovation Activity?, January 2008

2205 Sascha O. Becker and Mathias Hoffmann, Equity Fund Ownership and the CrossRegional Diversification of Household Risk, January 2008

2206 Pedro R. D. Bom and Jenny E. Ligthart, How Productive is Public Capital? A MetaAnalysis, January 2008

2207 Martin Werding, Ageing and Productivity Growth: Are there Macro-level Cohort Effects of Human Capital?, January 2008

2208 Frederick van der Ploeg and Steven Poelhekke, Globalization and the Rise of MegaCities in the Developing World, February 2008 